Customer resistance to tourism innovations: entrepreneurs' understanding and management strategies

\author{
(Forthcoming in Journal of Travel Research) \\ Isabel Rodriguez Sanchez \\ School of Hospitality and Tourism Management \\ Faculty of Arts and Social Sciences \\ University of Surrey \\ Guildford GU2 7XH \\ United Kingdom \\ E-mail: isabel.rodriguez@surrey.ac.uk
}

\author{
Allan M. Williams \\ School of Hospitality and Tourism Management \\ Faculty of Arts and Social Sciences \\ University of Surrey \\ Guildford GU2 7XH \\ E-mail: allan.williams@surrey.ac.uk \\ Hugo García Andreu \\ Universidad de Alicante \\ Campus de San Vicente del Raspeig \\ Ap. 99 E-03080 \\ Spain \\ E-mail: hugo.andreu@ua.es
}

This research has been supported by the European Union Horizon 2020 Research and Innovation programme [grant agreement 700893]. 


\title{
Customer resistance to tourism innovations: entrepreneurs' understanding and management strategies
}

\begin{abstract}
Customer resistance is the greatest risk to innovation for the entrepreneur. The aim of this exploratory study is to provide insights into this underdeveloped area in the tourism innovation literature. A qualitative approach is adopted to understand the resistance experienced by 57 entrepreneurs when introducing their innovations into the market, the causes and the actions taken to minimise resistance. Findings indicate that most entrepreneurs often encounter resistance from sceptical customers, satisfied with their status quo and with no or low appetites for innovation. The analysis reveals two main sources of resistance: the association of the innovations with particular risks, and the customers' lack of understanding of the innovation value. Communication strategies are crucial to decrease the associated risks and for trust building. The paper provides a critical perspective on the challenges faced by innovators, challenges which are often overlooked given the near-iconic status of innovation in studies of economic development.
\end{abstract}

\section{Keywords}

Tourism innovation, customer resistance, entrepreneur, perceived risk 


\section{Introduction}

Innovation is essentially and literally a risky business and the literature reports high failure rates for innovation (Heidenreich and Spieth 2013; Gourville 2006). While risks exist in all stages of the innovation process, perhaps the most critical stage is innovation diffusion (Rogers 1983) since the market place is the battleground where the fate of the innovation will be decided. That battle frequently is played out against a background of customer resistance (Ram 1989), understood as a negative outcome of an innovation evaluation (Kuester and Hess 2009). More often than might be expected from reading the often advocative innovation literature, new ideas generate uncertainty in the minds of potential adopters who can perceive them as a known or unknown risk or as a potential threat (Förster, Marguc, and Gillebaart 2010). Moreover, the more radical the degree of change associated with the innovation, the more likely it is to conflict with current habits, ways of thinking and previous experience, and to encounter substantial resistance (Kleijnen, Lee, and Wetzels 2009; Oreg 2003). For the entrepreneur, customer resistance is usually the, or at least one of the, greatest risks to innovation (Heidenreich and Kraemer 2016), and overcoming this resistance is of course a key to success, as exemplified by the acceptance of travel cheques, credit cards, and budget airlines at differ points in the evolution of tourism (Hall and Williams 2008).

While the existence of customer resistance is widely acknowledged, the literature about innovation resistance is fragmented, still very theoretical (Kleijnen et al. 2009) and sparse in tourism research. Resistance as the main focus of research has been studied in the context of the early phase of online purchase of travel services (Bigné, Sanz, Ruiz and Aldas 2010; 
Kim, Kim, and Shin 2009; Kamarulzaman 2007), and the use of mobile devices before and during travel (Gonzalez-Reverte, et al. 2018; Tussyadiah and Wang 2016). This literature has particularly addressed the issues of resistance and risks in the area of technologies (not necessarily considered in terms of innovations) mostly incorporating the perspective of the tourist as final customer. However none of these studies have analysed the resistance experienced by entrepreneurs offering multiple types of innovations to different types of customers (intermediate or Business-to-business -B2B- and final or Business-to-customer B2C-). Exceptionally, Rodriguez, Williams and Brotons' (2017) overview of the tourism innovation process found evidence of significant resistance to different types of innovations from a range of customers when working with more conservative, technology-laggard subsectors.

This paper aims to provide new insights into this underdeveloped but critical area in the tourism innovation literature. A qualitative approach is adopted which draws on 57 in-depth interviews with tourism entrepreneurs in Spain and the UK to address the sources of customer resistance as perceived by the entrepreneurs and the strategies used to manage these.

The paper is organised as follows. Initially, a literature review is presented to provide a conceptual framework of the key issues which will be explored empirically with tourism innovations such as innovation resistance, influencing attributes of an innovation diffusion and innovation risk perception. This is followed by an outline of the research methods and sampling of entrepreneurs and innovations. The last two sections incorporate the analysis in relation to innovation resistance and its management strategies and the conclusion of the 4 
study.

\section{Theoretical Review}

Innovation is notoriously difficult and new innovations are prone to failure. A review of recent generic studies (Castellion and Markham 2013) considers that some $40 \%$ of innovations fail, with customer resistance being among the primary causes. This poses the question of why, if innovations offer potential improvements over existing products, they are resisted. Different literature strands, mostly generic rather than tourism-specific, have addressed this question revealing that the drivers of resistance include both innovationspecific and customer specific factors. Figure 1 provides a framework to discuss the theoretical relationships examined.

According to the innovation diffusion literature, the attributes of an innovation play a key role in influencing innovation acceptance whether positively or negatively (Rogers 1983, 211). The first attribute is relative advantage or the degree to which an innovation is perceived as being better than the idea it supersedes, adding significant value in at least one of a number of sub dimensions (Vogt 2013): economic profitability, low initial cost, savings in time and effort, immediacy of reward, status, etc. This is closely related to performance expectancy or the degree to which using the innovation will provide benefits or is useful to potential customers (Venkatesh, Thong, and Xu 2012). The other attributes are: compatibility (consistency with existing values, past experiences and the needs of potential adopters); observability (degree to which the results of an innovation are visible to others); complexity (the degree to which an innovation is difficult to understand and perceived as difficult to use); and trialability (possibility to experiment with the innovation). 5 
There is considerable literature mainly based on the work of Davis (1986), the Technology Adoption Model (TAM), documenting how users' perceptions of the innovation (especially of relative advantage, ease of use and compatibility) influence their acceptance (thus a positive adoption behaviour), in contexts such as mobile banking and other internet-based services (Lin 2011) including travel services (Bigné et al. 2010; Kim et al. 2009), the use of mobile devices when travelling (Kim, Park and Morrison 2008), and the use of virtual reality for travel planning (Disztinger, Schlögl and Groth 2017). On the contrary, few authors have explicitly explored rejection or a negative adoption behaviour (Talke and Heidenreich 2014). The subjective perceptions of the innovation are of course variable and are determined by individual and contextual factors. In general, the innovation must be perceived as being different from existing alternatives in a way that is meaningful to customers, that is as desirable and feasible (Sethi, Smith, and Park 2001). Desirability refers to either a functional benefit (the innovation is useful or has a utilitarian side) or a hedonic benefit creating appropriate experiences, feelings and emotions (Wang, Cole and Chen 2018; Venkatesh et al. 2012; Kulviwat el al. 2007). The hedonic component is prominent in most tourism innovations which are designed to arouse pleasure and enjoyment in the customer, especially final customers. Initially, these types of innovation could encounter less resistance since they activate a pleasant and positive emotionally driven behaviour. This is the case of users interacting with virtual/augmented reality in the context of travel planning (Disztinger et al. 2017) and cultural heritage (Haugstvedt and Krogstie 2012) in which enjoyment was a good predictor of behavioural intention to use.

This leads to the second determinant of innovation success or failure: customer-specific 6 
factors including personality, risk perception and attitude, behavioural patterns or the individual's specific context or situation (Figure 1). Rogers (1983) distinguished five different groups of individuals with different attitudes, levels and types of resistance towards innovation, affecting the timing of adoption: Innovators, Early Adopters, Early Majority, Late Majority and Laggards. Innovators and early adopters are more favourable toward new ideas thanks to their ability to cope with uncertainty and to deal with relatively abstract information: they are more risk- and uncertainty-tolerant.

Another literature strand has shifted attention from those who adopt to those who do not adopt innovations (Szmigin and Foxall 1998) and the associated forms of customer behaviour: rejection, postponement and opposition (Figure 1). Rejection implies an active evaluation by the customer which results in a strong disinclination to adopt the innovation because of suspicion of its unproven novelty or the innate conservatism of the customer (Kleijnen et al. 2009). Some authors also consider that sometimes innovations are rejected immediately without even being evaluated if they are perceived as insufficiently motivational or entail an obvious relative disadvantage. Postponement refers to symbolical acceptance of the idea but procrastination in the adoption decision, e.g. the customer requiring more information, or time to process the available information or to see how the product develops. However, an initial positive attitude may still result in rejection (Kleijnen et al. 2009; Szmigin and Foxall 1998). Finally, opposition refers to those customers who not only reject the innovation as unsuitable but also seek to discredit or sabotage it (Davidson and Walley 1985). Opposition might also be associated with the behaviour of established industry players who perceive risks stemming from radical innovations, for example, to 
transport companies utilising smartphone mobile Apps, such as Cabify and Uber, as putting at risk taxi drivers' jobs.

Innovation resistance incorporates a component of customer risk perception. Although the concepts of risk and uncertainty have been used interchangeably and they can coexist, there is a distinction between them. Knight (1921) distinguished between risk (known risks where some measure of probability can be attached to possible outcomes) and uncertainty (unknown risks). This study mostly uses the term risk, and more precisely the term 'perceived risk', associated in the marketing literature with an expectation of a potential loss, in relation to performance, social, physical, financial, psychological, time, frustration, security, privacy, etc. (Dowling 1986; Ram and Sheth 1989). The overall risk could be constituted of a combination of several forms of losses, while certain types of services are more commonly associated with particular risk dimensions: for example, performance, psychological, time and privacy in the sphere of electronic transactions (Cunningham et al. 2005), loss of control over the tourism experiences by travellers in the context of travelling and the use of smartphone (Tussyadiah and Wang 2016) or physical risk with adventure tourism (Crouch 2013). These risks are always subjective not least because it is often impossible to assess them accurately (Mitchell 1999). According to Bauer (1960), even if the potential customer could calculate the risks, these so-called 'objective' assessments would be given meaning only by their subjective opinions. Some products might be inherently more risky than others but what matters is the level of risk attached to them by customers and whether this perceived level of risk is strong enough to reject the innovation. Resistance to robots with a human appearance exemplify the challenges faced by innovators. 
When confronted with risky choices, customers, in common with the population generally, tend to be change averse since changing behaviour entails costs (transaction costs when changing from one product to another, learning and obsolescence costs, etc.). This status quo bias (Kahneman, Knetsch and Thaler 1991) represents a tendency for individuals to be satisfied with a status quo because the disadvantages of change loom larger than the advantages. Thus, contrary to what the innovation literature often assumes (that customers are open to change and interested in evaluating new products), an initial resistance to change is probably an expected customer response (Ram 1989; Talke and Heidenreich 2014). Change aversion has been considered a key structural and behavioural characteristic of tourism, creating barriers to innovation (Hjalager 2002; Camison and Monfort-Mir 2012; Najda-Janoszka and Kopera 2014). In their work with tourism innovations, Rodriguez el al. (2017) also documented that changing customer habits in relation to the use of technology was difficult in some subsectors considered "technology laggards" such as ski resorts and restaurants. When making a decision, customers balance the extent to which an innovation satisfies specific needs and the associated sacrifices. If sacrifices are too high, customers are likely to reject an innovation, even if it provides considerable benefits (Vogt 2013). Individuals' valuation of risks relating to gains may also be different from their valuation of attitudes toward risks concerning losses. Tversky and Kahneman's (1986) prospect theory contends that individuals are 'loss averse', with losses in utility being valued more than similarly sized utility gains. Together with loss aversion and the above mentioned status quo bias, Kahneman et al. (1991) described a third "anomaly" in economic behaviour, the endowment effect, whereby individuals often demand far more recompense to give up an 
object than they would be willing to pay to acquire it. In tourism research, Cohen, Prayag and Moital (2014) also highlight an apparent irrationality underlying hedonic and emotionally-driven behaviours which deserves further attention.

Given that resistance is to be expected for many innovations, especially those which lead to a significant change in the customer's behaviour, the question arises as to whether and how the entrepreneur can seek to minimise resistance? Gourville (2003) advises entrepreneurs to expect slow adoption and to manage their resources accordingly to avoid the risk of this being depleted too quickly, that is, resistance acceptance. Another strategy is changing or modifying the innovation characteristics to make it more compatible with the market (Szmigin and Foxall 1998; Ram 1989). A third strategy is to implement appropriate information and communication strategies to reduce the perceived risk and to influence trust positively (Oreg and Goldenberg 2015). According to Mayer et al. (1995), perceived risk and trust are inversely related and in some sectors, such as online banking and travel services, increased trust reduces fears and perceived risks (Lin 2011; Wu and Chen 2005; Bigne et al. 2010). Trust is a social construct (Williams and Baláž 2011) and it is often defined as the belief of an individual in the reliability and integrity of an exchange partner, associated with qualities such as being consistent, competent, honest, fair, responsible, helpful, and benevolent (Morgan and Hunt 1994). This is especially important in an innovative start-up where the firm/product usually has a limited track record or market reputation. Communication might include experimentation through use of demonstrations (Heiman, McWilliams, and Zilberman 2001). These give customers the opportunity to experience/learn from the product before the purchase, thereby reducing risks, and are 10 
known to increase the likelihood of purchase; this is known as the 'foot in the door' effect. Nowadays, demonstrations, commonly involve technologically trialable products in the form of free trials or time-limited product versions. Online videos of destinations or accommodation represent one form of demonstration in tourism - essential because consumption occurs in situ at the point of delivery. Rodriguez et al. (2017) also documented trust issues towards technological innovations where customers considered they had not been validated by other tourism users, and this had to be overcome by offering trials and demos. Experimentation can also involve training of employees since it has a positive effect on their perception about coping with change (Oreg and Goldenberg 2015). Communication strategies are crucial in order to decrease concerns in relation to certain types of risks such as privacy or security concerns, and they imply working with clear statements of guaranteed transactions or privacy policies (Heidenreich and Kraemer 2016). Communication strategies also advise accurate market targeting, and focussing on customers who value the benefits of innovation in the face of its drawbacks. As the science of networks emphasises, more important than the intrinsic value of the innovation is the structure of the network it impacts on since it is by imitation or social contagion that individuals make decisions (Watts 2003). This is why word-of-mouth and opinion leadership from peers or members of other reference groups have proved to be so significant in innovation acceptance (Ram 1989). If all three strategies fail to eliminate or sufficiently reduce resistance, the innovators will have to face a pivoting or market exit strategy (see Figure 1)

Figure 1. Conceptual model 
While the generic literature indicates both the importance of how innovators understand customer resistance, and the strategies to overcome this, the tourism literature on these two issues is limited and fragmented. Although there is a considerable overlap between the generic service and tourism literatures on innovation (Hall and Williams 2008), the distinctiveness of tourism (temporal demand variations, the coterminality of production and consumption, information intensity, and labour force competences), underline the need for a sector specific analysis of these issues.

Based on this review of the literature and the research gaps highlighted, the paper addresses two research questions. First, how do tourism entrepreneurs understand the main sources of resistance from their potential customers and the reasons for these negative responses? And, secondly, what strategies do tourism entrepreneurs use to manage customer resistance to innovation adoption?

\section{Methods}

Given the exploratory character of this research (Stebbins 2011) and the complexity and subjective nature of customer resistance to innovation, a qualitative approach was adopted (Miles and Huberman 1994; Creswell 2009). This study forms part of a wider research project on the complexity of innovation pathways. This involved asking questions about the risks found along all stages of the innovation process but giving special attention to customer resistance. Innovators were asked to tell their stories about encountering customer resistance during the process of innovation diffusion and the strategies they implement to minimise or avoid different forms of resistance. How the entrepreneurs 
understand this, what meaning it has for them and how they explain things is the emic approach to the phenomenon, that is, from the perspective of the subject.

The first challenge was the identification of innovative - as opposed to any - entrepreneurs in tourism since there are no comprehensive data sources at country or EU-level, particularly for startups. Therefore, it was decided to adopt snowball sampling (Goodman 1961), following the logic of Respondent-Driven Sampling (RDS) as the most appropriate method when domain experts cannot easily be located (Heckathorn 1997). In order minimise the risk of encapsulated networks, the research used multiple entry points unknown to each other and geographically dispersed; that is, parallel snowball networks. Initial respondents (entrepreneurs or key informants) were identified in a range of settings: governmental institutions with entrepreneurial programmes providing funding, tutoring or acceleration, private investors, entrepreneurial communities, universities, innovation research centres and tourism and hospitality industry organizations. Two main criteria were used to identify innovative entrepreneurs and reduce some sources of variation in the sample: 1) degree of novelty (from incremental to radical according to Schumpeter 1934) in order to select innovative as opposed to replicative entrepreneurs (Baumol 2010); 2) startups purposely created to develop the innovation but at different stages of their business lifecycle (as opposed to corporate innovation in established firms). All the firms suggested by our informants were discussed and validated within the research team. There was a high participation rate, $85 \%$ of those approached agreeing to be interviewed. The final sample was constituted of 29 start-ups/innovations in Spain and 28 in the UK. Initially, the research considered that different entrepreneurial and innovation contexts were likely to have a 13 
major influence on customer resistance to the innovation process. This partly explains the choice of Spain and the UK: Spain has developed strong governmental programmes of support to innovative entrepreneurs, while the UK presents a more neo-liberal context based on attractive tax incentives. The choice of the two countries was also informed by the composition of the team, and their possession of appropriate networks to initiate the snowball sampling, and the language skills to undertake the in-depth interviews. The participants were active co-founders of the innovative start-ups with ages comprised between 25 and 45 and very diverse educational backgrounds with prevalence of the degrees in humanities (13), business (12), engineering (8), music (3) and MK (2) among others. Only 7 entrepreneurs had studied tourism or hospitality related degrees. At least 18 entrepreneurs had Masters level qualifications in business or MBAs. The professional background of 24 entrepreneurs was related to tourism and hospitality and a total of 28 entrepreneurs revealed having had previous experience in running a business -only 9 of which were hospitality related- having failed 9 of them in their attempt to launch other innovative business ideas.

The narratives of the 57 entrepreneurs were gathered through in-depth semi-structured interviews, both face-to-face and via Skype (given their geographical dispersion). The interview script was pre-tested with two entrepreneurs in English and Spanish. The interviews, undertaken between November 2016 and February 2017, lasted an hour on average. Appropriate ethical research guidelines were followed relating to consent and confidentiality. The interview process ceased when saturation of the main revealed themes was reached (Bowen 2008). The main themes had already emerged after some 30 cases 14 
while the remaining interviews were undertaken to consolidate these and to draw out different nuances in the narrated experiences of a purposely heterogeneous sample drawing from the range of firms that fitted our broad selection criteria. Saturation was reached when the team agreed that no new categories or themes were emerging and/or altering the previous codified data.

The interview recordings were transcribed into written form by the three members of the research team as soon as possible after the interview was conducted. All three members had clear and agreed instructions of how this task should be performed (e.g. level of description detail and memos of codification as a basis for the new transcriptions). The method chosen to analyse the experiences, meanings and the realities of the innovators (based on an essentialist or realist theoretical framework) was the thematic analysis. This is an accessible and flexible analytic method, considered a methodological approach in its own right (Braun \& Clarke 2006). The six steps procedure favours a systematic treatment of data and the identification of themes through an inductive approach after the initial authors' familiarisation with the data while transcribing, reading and re-reading and data coding. A theme represents some level of patterned response or meaning within the data set and themes need to be defined, named, reviewed and refined ensuring they formed a coherent pattern; extracts from the transcriptions are selected to support the validated themes. The rigour and trustworthiness of the research is provided by several means (Tracy 2013): 1) through a purposeful sampling choosing the individuals that best fitted the parameters of the project's research (Patton 2002); 2) providing thick description of the most prevalent themes to report the data's complexity truthfully, and allowing the reader to come to their 15 
own conclusions; 3 ) using multiple assessments and maintaining a reflective dialogue among all three research team members throughout the analytic process. This involved careful internal checking of the descriptive accuracy of each interview both during and after the transcriptions, the practice of inter-coding reliability (e.g. cross checking of coding strategies and interpretation of data by each team member including memos of the coding and its modifications), and a common co-creation of meaning and consistency in understanding of the emerging themes (Miles \& Huberman 1994).

\section{Types of innovations analysed}

This study incorporates a variety of types of innovations including innovations in more traditional hospitality businesses (e.g. themes hotels) and of the travel sector (e.g. niche travel agencies). However, there is a predominance of technology-related innovations in the sample (see Table 1). These technologies tend to focus on increasing productivity and performance in tourism firms (management of food waste, human resources, quality, suppliers, benchmarking), and adding value to the customer experience (more visual and interactive forms of communication and promotion, accessibility to resources and services). As Table 1 indicates, the sample includes both e-business innovations (offering online services) and off-line businesses, with a business-to-business (B2B) orientation or targeting direct customers or business-to-costumer (B2C). New forms of Customer to Customer (C2C) business models that facilitate the transaction of services between customers are also included. A significant number of innovations analysed have been developed by entrepreneurs from outside the field of tourism, especially in the case of technological innovations. 


\section{Findings}

Data gathered from the two main topics discussed - innovation resistance and resistance management strategies - is presented in the next two sections.

\subsection{Innovation resistance}

A significant number of innovators mentioned difficulties associated with the status quo satisfaction of the targeted customers who were sufficiently comfortable with what they were already using/doing; this accords with the status quo bias described by Kahneman et al. 1991. These customers already had a procedure/alternative tool or product that the innovators were trying to improve, in most cases through the introduction of new/alternative technologies. The producers of a body drier for hotels report that: "many people still prefer using a towel and are sceptical about drying their body with air" [E42]. According to the innovators, these potential customers were confronted with innovations that required them to adopt new behaviours different to their established habits. For example this entrepreneur comments that: "replacing pen and paper with digital forms of data collection in restaurants and hotels has been a handicap. Established habits have been my main competitor" [E12]. Exploring further this picture of change averse customers, two main sources of resistance emerged in the analysis. Both are closely interrelated and, unsurprisingly, some interviewees mentioned them concurrently.

\section{Theme 1: Innovations' perceived risks}

Many entrepreneurs reported that the association of their innovations with a particular risk was a cause of customer resistance. The most common types of risks found in the analysis were: 


\section{Performance risks inherent to innovation}

Entrepreneurs frequently mentioned that the cause of resistance was the customers' lack of confidence in a product/service that had not been previously tested by other users. This is what Rogers (1989) would describe as lack of results' observability. The customers had problems in determining how well the innovation was going to perform, or even in understanding the potential benefit (performance risks). In these cases the customer perceived that the risks of being the first to acquire the innovation were high since there were no observable prior experiences, and clear points of reference which allowed the innovation to be compared and evaluated with confidence. In the case of substantially new products, there are also no alternatives to make a comparison with (Veryzer 1998). This entrepreneur reported that a common question from customers was: "Who else has this? In my environment nobody has this" [E31]. This quote reflects the intention of postponing the decision until peer observation and or comment is possible (Kleijnen et al. 2009). Another tech entrepreneur reports being asked: "how many times have you done this before?" providing the logical answer: "never before since it is an innovation!".

Lack of business reputation risks

A small group of entrepreneurs associate the causes of resistance with how their lack of reputation or credibility increases customers' perceived risks of the innovations: "there's lots of resistance always to a new company people aren't familiar with" [E33]. Reputation develops over time, and is usually the product of years of demonstrated competence, which start-up entrepreneurs are unlikely to have had sufficient time to develop. This was especially critical in their relationships with large established companies as customers (e.g. 18 
B2B innovations). Concerns are illustrated by quotes such as: "it is risky for managers to acquire technology from an unknown start-up since if things go wrong they can get fired by their superiors whereas there is no risk for them when buying products from IBM" [E27]. Reputation is also a multifaceted construct which can refer not only to the general corporate reputation but also to context-specific reputation (Henard and Dacin 2010) which in this study was the challenge faced by entrepreneurs who lacked previous links with the tourism sub sector they are targeting.

First movers' risks

This is strongly connected with the two previously described types of risk. Some entrepreneurs, mostly with technological innovations, consider that the resistance they encountered stemmed from being pioneers and having arrived too early at the market. They considered there was a combination of having a disruptive and breakthrough technology (e.g. utilising augmented reality in museums and hotels) and the market not being sufficiently mature, ready and receptive for the type of product offered as this entrepreneur notes: "it was the most advanced museum guiding system of the market, perhaps too advanced for the moment and the country...if I had launched this in Japan this would have been a different story" [E6]. One entrepreneur refers to the importance of the "right timing to the market, not too early, not too late" [E10]. Another entrepreneur states that "being first in the market is often negative" [E15], having realised that his determination to be the market pioneer had been a big mistake because, over time, the market had become more aware, familiarised and receptive (e.g. similar tools were being offered to restaurants, his target market). This is in line with Oreg and Goldenberg's (2015) statement that first mover 19 
advantage is a myth since pioneering does not ensure market leadership unless (and uncommonly) pioneers manage to translate their success with early adopters into main market domination (Watts 2003). Being pioneer also complicates the task of making the results visible to others (Rogers 1983).

\section{Control and transparency risks}

These types of risks are associated with innovations that impose further control requirements on internal working procedures and operative practices (Oreg and Goldenberg 2015); for example, a new process that requires the user to record when and how the task it is performed. This was perceived as a control mechanism and a loss of autonomy, together with the fear that workplace practices could be exposed and come under the surveillance of senior managers, especially in the hospitality sector. Similarly, tools based on open sources and transparent information were perceived as risky since the customers were afraid of negative reviews from their own customers, and of lacking control over how this negative information could be displayed. One entrepreneur recalls being told by many restaurant owners: Oh God, is this a feedback form that is going to expose how I run the business?[E11]. Transparency also implied endangering past values and traditional practices which could be beneficial for the company or for intermediaries in the supply chains: for example, intermediary suppliers of food products to restaurant were concerned that apps would undermine their roles and industry norms. This would be a case of an innovation being incompatible with the values and norms of the social system within which it aims to be introduced (Rogers 1983). 


\section{Psychological risks}

A few cases of resistance were reported where the innovation did not cohere with the selfimage or self-concept of the target customer, and this represents a psychological risk. In one example, an entrepreneur offering a technology to monitor and reduce food waste in restaurants/hotels faced resistance from professional chefs who do not think that they create waste unnecessarily. As he explains: Well, they're professional chefs and they don't want to be viewed, obviously, as unprofessional. However, the reality is we all make-all the industry creates more waste than it should. ......The biggest issue is getting people to look inside themselves and understand "actually, we could be doing a bit better than what we're doing." [E19]. In this case the resistance is connected with the cognitive rigidity of a dogmatic individual when evaluating the self, finding it difficult to admit that previous practices might have been inadequate (Oreg 2003). A second case is illustrated by an entrepreneur offering a technology to restaurants to sell the surplus food that the customers reject, which clashed with their perception that offering food at reduced prices was a risk because it could harm their business brand image.

Privacy and safety risks 
Innovations which implied the collection of personal information, or the sharing of confidential firm data, were perceived as being risky (Dowling 1986; Ram and Sheth 1998). The same applied to those which posed safety concerns for customers about their properties (e.g. a housesitting network) or their children (e.g. a collaborative platform of mums providing mutual care support for children while on holiday). These later two cases correspond to innovations based on the sharing economy in which reputation and trust play a key role.

Other types of risks

Other types of risks perceived by the customers were the risk of effort and time investment and a few entrepreneurs expressed sentiments such as: "every change involves work and people do not want to assume more workload" [E16] (similar sources of resistance were reported by Kanter 1985 and Oreg 2003). Customers of a highly innovative restaurant were also perceived to manifest a loss perception (value for money) and frustration when not seeing traditional and expected types/amount of food on the menu.

\section{Theme 2: Lack of understanding of the relative advantage and benefit of the innovation}

Most entrepreneurs identified this issue as a risk they feared and indeed it had materialised for a significant number of them as it was the second most frequently referred to cause of resistance. They considered that the innovations were not meaningful for the customers since they could not appreciate the benefits and relative advantages provided. This was a source of frustration for the innovators who literally could not understand the customers' 'failures' in this respect. This is exemplified by those entrepreneurs offering a technological 22 
tool to restaurants which in their opinion provided significant advantages over the existing practices for collecting customer feedback and the consequent potential to improve quality and reputation:

Restaurants aren't willing to accept technology. They've already paid for mystery diners who .... leave a half-an-hour report. I don't understand that... we give the opportunity to reach 800 or 900 customers, your actual customers, for the same price as a single mystery diner. ..... It's very frustrating because there's definitely a barrier in people's perception, they are kind of stuck in their ways [E18].

In this specific case, the entrepreneurs attribute the resistance to the characteristics of the market they intend to enter: restaurants which stick to old habits are satisfied with the status quo and lack an appetite for technological innovations. Previous studies have also reported that this sub-sector seems to be particularly traditionalist and slow in adopting technology-related innovations (Rodriguez et al. 2017; Chen and Elston 2013). A similar case is reported by another entrepreneur offering a technological tool which could undertake tasks that were not previously possible but who faced scepticism and rejection by hospitality customers who could not understand the potential of the technology embedded in the innovation:

Previous studies revealed that a manager can spend between 5 to 8 hours/week in a particular task. We have reduced this to 5 minutes or less but people consider this is too aggressive and they do not believe it is true. We have created a complex and powerful tool that escapes the understanding of non-professional hospitality 
managers [E10].

In this case, the lack of understanding is mostly related to the innovation's complexity attributes. With some new technologies the entrepreneurs can better understand the relative advantages than the customers who lack the same baseline knowledge or experience: "As an entrepreneur working daily on your innovation you really understand how your tool works and the benefit and it is easy to communicate it but then people look puzzled at you, like if you were crazy, saying they don't know what you are talking about" [E9]. As Cohen and Levinthal (1990) emphasised, related knowledge and expertise is crucial to adopt new ideas. Similar examples can be found with entrepreneurs willing to commercialise the idea of producing augmented reality cabins for hotels and destinations, and for guided visits to museums, or for entrepreneurs working with Big Data information to enhance travel agencies' benchmarking strategies. Similar reasoning applies in B2C innovations such as the case of an innovative chef offering a radical sea food gastronomic experience; with hindsight, he critically recognised that: "at the beginning it was such a radical proposal that customers coming into the restaurant and having a look at the menu were soon leaving. They could not understand what I wanted to transmit" [E45]. It is also important to also contextualise this innovative business (which later became a 3 star Michelin restaurant) in terms of its geographical location within an economically depressed region. In this case, the network structure where the innovation impacts has a low probability of finding customers aligned with the product (Watts 2003).

There are other cases in which the innovation has been designed with a philosophy and values which are not shared by the potential customers and this incompatibility (Rogers 24 
1983 ) is the cause of lack of appreciation and resistance. This is the case of a technological tool designed to provide feedback, motivation and reward to staff in hospitality firms:

There is a lack of understanding which is certainly a key issue...our platform has born in the philosophy of a much more technological, open, transparent and collaborative world whereas we were now working in a sector in which there are still many companies with a lot of fear to open environments, transparent information and potential customers' negative feedback [E11].

In this example, the discourse reveals how the entrepreneurs have imprinted their own values and beliefs on their innovations which are very different to those perceived by the target customers. In this case, the interpretation of resistance is through the lens of the entrepreneur's cultural parameters. Moreover, where the innovator sees a benefit, the customer might see a risk, as is exemplified by the transparency benefit/risk identified in the quote.

In another example, the innovation has been informed by a philosophy of delivering value to the service provided through human resources enhancement and offering the benefits of a long term competitive advantage. However, the outcome was a disappointment:

The tourism sector is very traditional, especially the hotel sector, this is what we are observing now ...they do not value or see the immediate benefit of investing in their employee's training. In the United States, for example, this is totally different and this has been not only shocking for us but it is like a wall that we have to jump [E14].

As the quote reveals the intangible value of the innovation cannot be demonstrated in 25 
terms of economic profitability in the short term, and it is difficult to show how the innovation will affect performance. As the entrepreneur recognises herself, the success of their innovation "will depend largely on finding those customers who share the same values as the innovation (value and enhancement of HR)" [E11]. It is interesting to note the surprise that this reaction from the potential hotel customers generates amongst entrepreneurs who did not have previous knowledge of this industry or came from a different business culture abroad.

Most of the cases highlighted seem to point to the fact that some innovations do not address customers' needs or critical aspects of their jobs/services. This is clearly manifested in this quote from an entrepreneur willing to add functionality (a human-machine interface with voice and image) to self-service check in/out kiosks in hotels in order to provide interactive destination information.

Hotels which have invested in self-service check in/out kiosks could integrate our assistant but they tell you that they do not need it even though it is a clear cost savings product [E5].

The situation portrayed here is a lack of understanding of the innovation value associated with the characteristics of the customers and their low levels of stimulation and exploratory behaviour towards novelty.

\subsection{Resistance management strategies}

This section addresses the key themes that emerged related to the different strategies implemented by the entrepreneurs in order to minimise the innovation resistance 
encountered. Most strategies are communication-related, seeking to emphasise the benefits of the innovation, reduce the perceived associated risks and influence trust positively.

\section{Theme: Education and information on relative advantage}

Providing the customer with information (either face-to-face or using visual techniques such as videos) was the most commonly used strategy to minimise all types of perceived risks (psychological, security, safety concerns, etc.) and to enhance the relative advantage of the innovation. This entrepreneur offering a technological tool to capture and benchmark operating data in holiday parks, campsites and glampling accommodation illustrates how they try to extend both information and training to all levels and using a mix of strategies including one-to-one customer education: "we have created a website and portal, which is clear and intuitive. We created a video to get across the initial broad idea and we will provide group training so we will hold workshops and we also have additional business opportunities in taking people further on a one-to-one basis" [E20].

Some entrepreneurs refer to the need to work on customer "education" about the importance of key aspects of their innovations (e.g. the human resources in the hospitality sector, the sustainability of food and the environment, etc.). Information oriented to enhancing the observability of results and the economic benefit of the innovation were considered crucial to minimise resistance and as one entrepreneur said: "numbers talk, it is a numbers conversation" [E12].

\section{Theme: Innovation demonstrations for customers to test}


In order to minimise the risks perceived in relation to the innovation performance, the entrepreneurs' strategy with technological innovations was to provide not only information but actual experience with the innovations (Heiman et al. 2001), offering demos or trials (temporary free or at a symbolic price). For example, entrepreneurs offering a body drier innovation for hotels comment: "testing is important not only for the customers to experience the new proposal of air drying in comparison to the traditional towel but also to get feedback to inform our marketing and communication policies" [E42]. In a few cases, the entrepreneurs narrate having offered the product for free as a testing ground to demonstrate to others that it works somewhere, successfully. However, even free trials were sometimes resisted as illustrated by this quote: "we have tried to implement our virtual reality system in several museums free of charge and none has accepted the proposal because lack of interest" [E6]. In this specific instance the entrepreneur was considering to pivot to more receptive and mature markets such as industry, medicine or marketing.

\section{Theme: Trust and credibility building}

When there is lack of reputation, the entrepreneurs have attempted to connect with bridging structures outside the firm (Kanter 1988): environments and forums or trade associations related to the innovation characteristics. For example, an entrepreneur accommodating tourists in homes of locals joined a sharing economy organisation and from within she piloted a new trust mark. Firms with governmental loans report that is was very beneficial to show the certification or logo of the bodies providing public funding to the firm, since it boosted credibility and made customers more receptive. Others mention the importance of gaining the customers' trust by involving, providing support and being close 28 
to people in the organisation (Oreg and Goldenberg 2015): "we train all of the staff and management initially. Which is good because we then get to know them and their issues and they get to trust us, as much as the system" [E16]. Specifically, the entrepreneurs whose innovations had associated security and privacy risks tried to emphasise how their technology protects the confidentiality of data or the importance of the personal/firm reputation as this housesitting network entrepreneur comments: “I don't think this stigma of having a stranger in your home will disappear for everybody, but I think as reputation becomes more visible online we will become more open to accepting people we don't know into our homes if we think we will benefit from it" [E54]. They often relied on a close and personal approach to the customer as this entrepreneur comments: "sometimes I Skype with them, talk to them on the phone, I try and meet them if I can so that they get to know that I'm a professional individual, that my reputation matters, and therefore the company's reputation matters" [E55].

\section{Theme: Target the innovative and organisational leaders}

Most entrepreneurs often try to normalise both a customer change adverse reaction and rejection (a possibility one must cope with) reflecting that: "not every customer is your target market. There would always be sceptical or people who don't necessarily understand your product and happy enthusiasts. Thus it is important to select well the right market segments and decide whether you need to convince the sceptical or just focus on those who believe it is a great idea [E8]. The latter would correspond with the innovators and early adopters who can help in demonstrating others the value of the innovation since as one entrepreneur explained: "then you point to them and say: look, it works for them" [E8]. This 29 
is well illustrated with this example of an entrepreneur willing to commercialise a smartphone-based access control and management system for hotels but who faces initial resistance because the customer does not perceive the relative advantage or need of the innovation. He therefore tries to target the most receptive or open to innovation hotels:

Hotels are usually not very innovative. Well, they are aware that sooner or later they will have to incorporate this system but they are not in a rush. I simply know that in the next five years every single hotel room will be opened with the mobile phone but currently the mentality of the hotel owner is: I am still a profitable business and I don't have that problem". This is why we try to target the most innovative profiles in the industry [E]].

Another key strategy was to convince those with capacity to be the leaders of change inside the firms as they are key nodes in a potential network to escalate the diffusion of the innovation within organisations (Watts 2003; Oreg and Berson 2011).

\section{Theme: Modify the innovation}

There are a few cases in which the strategy has been to modify the innovation characteristics to make it more compatible with the customer and lower the complexity. For example, augmented reality teleportation cabins being adapted to more flexible and mobile/portable formats.

\section{Discussion and conclusion}

This study constitutes a first exploratory attempt to provide empirical evidence of sources of 30 
innovation resistance in the tourism field. It aims to fill a knowledge gap in the tourism literatures on both innovation and entrepreneurship which have neglected the study of customer resistance. Its key contribution has been conceptually addressing the key issues into the integrative structure of a conceptual model (see Figure 1) which has served as the basis to explore empirically the entrepreneurs' perceived sources of resistance and how they deal with them.

The tourism industry has proved to be very attractive (because of its magnitude and economic importance) for innovators originating outside this domain who perceive opportunities to innovate (see also Rodriguez et al. 2017). However, these entrepreneurs who have potential to bring new ideas into tourism and hospitality businesses - often encounter resistance from customers, satisfied with the status quo and with no or low appetites for innovation. The picture emerging from the entrepreneurs' narratives also resonate with what previous studies have reported about tourism being a sector with innovation originating from outside, having a weak innovation culture and low absorptive capacity, being risk averse, and with considerable inertia (Camison and Monfort-Mir 2012; Hjalager 2002; Hjalager 2013; Najda-Janoszka 2014). While these characteristics are known, how they inform reluctance or laggardness in innovation are largely under-researched. The analysis of the entrepreneurs' perceptions reveals that the business customers of the sample seem to be highly driven by profitability goals, and this is the innovation attribute that seems to have a relatively positive influence on innovation acceptance (Vogt 2013). According to Crouch (2013) this is a common "homo economicus that seeks to maximise utility" customer behaviour. It is followed by other characteristics such as compatibility with 31 
customer needs and values, observability of results and low levels of complexity (Rogers 1983). As it was expected those innovations aiming to add value, providing services that do not address an important need, have faced more resistance since firms are still performing well without them.

The analysis and explanation of the sources of resistance to the tourism innovations analysed show that two aspects are of key relevance and have important managerial implications: the innovation attributes and the subjective perception of these attributes by customers, since these can develop into risks and perceived risks are a critical variable for innovation acceptance or resistance (see conceptual model in Figure 1). The findings also highlight the importance of understanding, anticipating and responding to the risks that customers perceive and which influence their decision making. The variety of risks identified poses the question about which of the risks can the entrepreneurs realistically hope to manage and reduce significantly, and which cannot be reduced and therefore they simply have to be aware of. There are always perceived risks inherent to any innovation (performance risks associated to something new without precedents) or to being a start-up (lack of reputation and trust issues). However some risks are strongly linked to the characteristics and the psychology of the target market and these deserve specific attention or ad hoc studies; for example, business environments risk averse to control and transparency. This connects with the importance of considering how the innovation is introduced within the innovation process (Kanter 1988; Rodriguez et al. 2017; Oreg and Goldenberg 2015) as an antecedent of resistance. The entrepreneurs analysed have provided valuable lessons in terms of possible strategies. In order to minimise some risks, 32 
and lack of understanding, it is important in the early stages to select the appropriate target markets, perhaps those which are more predisposed to change habits (the innovators and early adopters) and those who share the values that inspired the innovation. This implies a need for a better understanding of the customer behaviour and risk profiles. Second, it is important to understand the customers' self-concepts in order to adapt the innovations to be consistent with them and minimise the psychological risks. Of course, the values, beliefs and self-concepts of the customers are not immutable and there might be cases in which they can be challenged by the entrepreneur. However, challenging values and self-images could itself constitute a risk that will need measures and actions to minimise possible negative outcomes resulting from the customers' reactions. Changing values and consequently behaviours might also require patience and resources to give the market sufficient time to consolidate the innovations in the customers' minds (Gourville 2003), even allowing other competitors and early adopters to help in the process of innovation awareness and diffusion; yet, time is often what entrepreneurs most lack, given the need to generate revenue to cover the costs of the innovation. It is also important to consider an early involvement of prospective customers and undertake early product concept tests with them even though it has to be understood that such tests might still provide unreliable data on product acceptance. Castano et al. (2008) pointed out that when customers in such tests perceive a product as being far from market, they may overestimate the product benefitrelated features and underestimate the cost-related features. As the time to decision draws near, individuals become more concerned with the negative aspects of choice options. A range of communication strategies can be implemented to persuade the customers being 
education, information and demonstrations the most commonly applied.

In summary, this study represents a contribution to understanding innovation resistance in tourism. There has been very little theoretical reflection and empirical investigation (Kleijnen et al. 2009) of this topic in general, and it has been largely inexistent in tourism studies.

First, the analysis of the narrations indicates that very often the cause of resistance is attributed by the entrepreneurs to customers' lack of understanding of the value of the innovations. However, this is the entrepreneurs' subjective interpretation of the phenomenon. We acknowledge that, sometimes not only costumers exhibit bias in their assessment of the innovation but also the innovators. They have committed so much time and emotional energy to the innovations that they are contaminated by the "curse of knowledge", to the point that they're convinced that the product works, they recognize the need for it, and they are keenly aware of the shortcomings of existing alternatives (Gourville 2003). Thus there is a possible bias in the innovators overvaluing the usefulness of their products and blaming external factors when things go wrong (Rogoff et al. 2004). This links with the need for further research on the innovators' pathways, including more observation of key tasks that perhaps were poorly performed: insufficient co-creation of the idea with the customer, inaccurate understanding of customer behaviour of the targeted market segments, and inaccurate market research and testing. Those who reject innovations might not necessarily be exhibiting an irrational behaviour (Oreg and Goldenberg 2015) as some innovators stated. 
Second, there is a need for further understanding of the motivations to adopt and use innovations in the tourism and hospitality sector with special attention to the often affective nature of tourism consumption. Initially, what stems from our analysis is that in the case of business customers (especially from some sub-sectors) when confronted with innovations which require a more rational analysis these seem to be highly motivated by the economic profitability or benefit of the innovation. On the contrary the innovations which were reported to face no resistance were innovations with a more hedonic or affective component involving more gratification, promise of fun, pleasure and excitement in the experience (e.g. thematic hotels, niche travel agencies, restaurants). This has also been observed before in the case of mobile augmented reality in cultural heritage settings (Haugstvedt and Krogstie 2012). Thus, there is scope for research about the role of emotions as a cause of successful diffusion and whether innovations which provide hedonic (affective) gratifications are perceived as less risky and face less resistance than those which are designed to satisfy instrumental, utilitarian motivations (Chaudhuri, Aboulnasr, and Ligas 2010; Wang et al 2018). This is an underexplored area in the context of tourism innovations. There is also scope for comparative research to identify the extent to which customer resistance in tourism is specific to the sector, and this calls for systematic comparative analyses of tourism to selected, specific sectors, such as retailing, or in the use of particular IT platforms.

We also acknowledge some limitations of this research which open avenues for further investigation. It has not been possible to determine the fate of the innovations facing resistance, that is whether they failed or the resistance was overcome. When interviewed, 35 
at least two entrepreneurs (with augmented reality technologies) were already pivoting from the tourism industry to other more promising industrial sectors. There is thus a need for more longitudinal studies of the innovations. Most research is cross sectional and or treats the innovation process as a unity providing a snapshot in time, whereas understanding the dynamic and complex nature of the process of innovation requires a longitudinal approach (Perks and Roberts 2013).

Future research also suggests the need for first hand observation of the customers who resist innovations. In general, the research about innovation resistance has tended to focus on customers who show little resistance which according to Oreg and Goldenberg (2015) represents only some $20 \%$ of the potential market, neglecting the attitudes and behaviours of the remaining $80 \%$ who resist innovations. It is important for policy makers, innovators and all the entrepreneurial stakeholders to extract lessons from failed innovations in tourism. It would also be helpful to study quantitatively different individuals' attitudes towards some fixed set of innovations taking into account multiple influencing factors socioeconomic, cultural and organisational, individuals' risk tolerance/risk taking characteristics (Pizam et al. 2004), etc. This could also involve experimental research.

Contrary to initial expectations, the research did not find significant differences between countries in respect of customer resistance to innovation. Market resistance seems to be related more to the characteristics of the innovations and the sectors of activity, rather than to systematic national differences in markets or policy frameworks. This may be related to the internationalisation of markets, and strong convergence in customer experiences of the internet, but these are topics to be further investigated in future research. 


\section{References}

Bauer, R. 1960. “Consumer behavior as risk-taking" In Dynamic marketing for a changing world, edited by R. S. Hancock, 389-398. Chicago: American Marketing Association.

Baumol, W. 2010. The Microtheory of innovative entrepreneurship. Princeton, NJ: Princeton University Press.

Bigné, E., S. Sanz, C. Ruiz, and J. Aldás. 2010. “Why some internet users don't buy air tickets online" In Information and Communication Technologies in Tourism, edited by U. Gretzel, R. Law, and M. Fuchs, 209-221. Springer, Vienna.

Bowen, G. A. (2008). "Naturalistic inquiry and the saturation concept: a research note". Qualitative research 8 (1): 137-152. https://doi.org/10.1177/1468794107085301

Braun, V., and V. Clarke. 2006. "Using thematic analysis in psychology". Qualitative Research in Psychology 3 (2): 77-101. http://doi.org/10.1191/1478088706qp063oa

Camison, C., and V. Monfort-Mir. 2012. "Measuring innovation in tourism from the Schumpeterian and the dynamic-capabilities perspectives". Tourism Management 33: 776789. https://doi.org/10.1016/i.tourman.2011.08.012

Castaño, R., M. Sujan, M. Kacker, and H. Sujan. 2008. “Managing consumer uncertainty in the adoption of new products: temporal distance and mental simulation". Journal of Marketing Research 45 (3): 320-336.

Castellion, G., and S. Markham. 2013. "Perspective: New product failure rates: Influence of 37 
argumentum ad populum and self-interest". Journal of Product Innovation Management 30 (5): 976-979. https://doi.org/10.1111/j.1540-5885.2012.01009.x

Chaudhuri, A., K. Aboulnasr, and M. Ligas. 2010. "Emotional Responses on Initial Exposure to a Hedonic or Utilitarian Description of a Radical Innovation". Journal of Marketing Theory and Practice 18 (4): 339-359. https://doi.org/10.2753/MTP1069-6679180403

Chen, S., and J. Elston. 2013. "Entrepreneurial motives and characteristics: An analysis of small restaurant owners". International Journal of Hospitality Management 35: 294-305. https://doi.org/10.1016/j.ijhm.2013.07.002

Cohen, W., and D. Levinthal. 1990. “Absorptive-Capacity: A New Perspective on Learning and Innovation". Administrative Science Quarterly 35 (1): 128-152.

Cohen, S., G. Prayag, and M. Moital. 2014. “Consumer behaviour in tourism: Concepts, influences and opportunities". Current Issues in Tourism 17 (10): 872-909. https://doi.org/10.1080/13683500.2013.850064

Creswell, John W. 2009. Research design: qualitative, quantitative, and mixed methods approaches. Los Angeles: Sage.

Crouch, Geoffrey I. 2013. "Homo Sapiens on Vacation: What Can We Learn from Darwin?" Journal of Travel Research 52 (5): 575-90. https://doi.org/10.1177/0047287512475219 Cunningham, L., J. Gerlach, M. Harper, and C. Young. 2005. “Perceived risk and the consumer buying process: Internet airline reservations". International Journal of Service Industry Management 16 (4): 357-372. https://doi.org/10.1108/09564230510614004 38 
Davidson, R., and P. Walley. 1985. “Computer fear and addiction: Analysis, prevention and possible modification". Journal of Organizational Behavior Management 6: 37-51. https://doi.org/10.1300/J075v06n03 03

Davis, F. D. 1986. "A technology acceptance model for empirically testing new end-user information systems: Theory and results". PhD diss., Massachusetts Institute of Technology, Cambridge.

Disztinger, P., Schlögl, S., and Groth, A. 2017. “Technology acceptance of virtual reality for travel planning" In Information and Communication Technologies in Tourism, edited by R. Schegg and B. Stangl, 255-268. Springer, Cham.

Dowling, G. 1986. "Perceived risk: The concept and its measurement". Psychology \&Marketing 3: 193-210. https://doi.org/10.1002/mar.4220030307

Förster, J., J. Marguc, and M. Gillebaart. 2010. "Novelty Categorization Theory”. Social and Personality Psychology Compass 4 (9): 736-755. https://doi.org/10.1111/i.1751$\underline{9004.2010 .00289 . x}$

González-Reverté, F., P. Díaz-Luque, J.M. Gomis-López, and S. Morales-Pérez. 2018.

"Tourists' risk perception and the use of mobile devices in beach tourism destinations". Sustainability 10: 413. https://doi.org/10.3390/su10020413

Goodman, L.A. 1961. "Snowball sampling". Annals of Mathematical Statistics 32: 148-170.

Gourville, J. T. 2006. “Eager sellers and stony buyers. Understanding the psychology of newproduct adoption". Harvard Business Review 84 (6): 98-106. 
Hall, C., and A. Williams. 2008. Tourism and innovation. London: Routledge.

Haugstvedt, A.-C., \& Krogstie, J. 2012. “Mobile augmented reality for cultural heritage: A technology acceptance study." Paper presented at the IEEE International Symposium on Mixed and Augmented Reality (ISMAR), Georgia, Atlanta, November 247-255.

Heckathorn, D. 1997. "Respondent-Driven Sampling: A new approach to the study of hidden populations". Social Problems 44: 174-199. https://doi.org/10.2307/3096941

Heidenreich, S., and P. Spieth. 2013. "Why innovations fail-The case of passive and active innovation resistance". International Journal of Innovation Management 17 (5): 1-42. https://doi.org/10.1142/S1363919613500217

Heidenreich, S., and T. Kraemer. 2015. "Passive innovation resistance: The curse of innovation? Investigating consequences for innovative consumer behaviour". Journal of Economic Psychology 51: 134-151. https://doi.org/10.1016/j.joep.2015.09.003

Heiman, A., B. McWilliams, and D. Zilberman. 2001. “Demonstrations and money-back guarantees: Market mechanisms to reduce uncertainty". Journal of Business Research 54 (1): 71-84. https://doi.org/10.1016/S0148-2963(00)00181-8

Hjalager, A. M. 2002. "Repairing innovation defectiveness in tourism". Tourism Management 23 (5): 465-474. https://doi.org/10.1016/S0261-5177(02)00013-4

Hjalager, A. M. 2013. "100 innovations that transformed tourism”. Journal of Travel Research 54 (1): 3-21. https://doi.org/10.1177/0047287513516390

Henard, D., and P. Dacin. 2010. "Reputation for product innovation: its impact on 40 
consumers." Journal of Product Innovation Management 27 (3): 321-335.

https://doi.org/10.1111/i.1540-5885.2010.00719.x

Hess, S. 2009. “Managing consumer's adoption barriers." PhD diss, University of Mannheim, Mannheim.

Hoeffler, S. 2003. "Measuring preferences for really new products." Journal of Marketing Research 40 (4): 406-420.

Janoszka, N., and S. Kopera. 2014. "Exploring barriers to innovation in tourism industry - the case of southern region of Poland." Contemporary Issues in Business, Management and Education conference 110: 190 - 201. https://doi.org/10.1016/i.sbspro.2013.12.862

Kahneman, D., J. Knetsch, and R. Thaler. 1991. "The Endowment Effect, Loss Aversion, and Status Quo Bias: Anomalies." Journal of Economic Perspectives 5 (1): 193-206.

Kanter, R. M. 1988. "When a thousand flowers bloom: structural, collective, and social conditions for innovation in organisations" In Research in organizational behaviour, edited by L. L. Cumming, 169-211. Greenwich, CT: JAI Press.

Kanter, R. M. 1985. Managing the human side of change. Management Review, 52-56.

Kamarulzaman, Y. 2007. "Adoption of travel e-shopping in the UK." International Journal of Retail \& Distribution Management 35 (9): 703-719.

https://doi.org/10.1108/09590550710773255

Kim, D., D. Ferrin, and H. Rao. 2008. "A trust-based consumer decision-making model in 
electronic commerce: The role of trust, perceived risk, and their antecedents." Decision Support Systems 44 (2): 544-564. https://doi.org/10.1016/i.dss.2007.07.001

Kim, D., J. Park, and A. Morrison. 2008. "A model of traveller acceptance of mobile technology." International Journal of Tourism Research 10 (5): 393-

407. https://doi.org/10.1002/itr.669

Kim, H., T. Kim, and S. Shin. 2009. "Modeling roles of subjective norms and eTrust in customers' acceptance of airline B2C eCommerce websites." Tourism Management 30 (2):

266-277. https://doi.org/10.1016/i.tourman.2008.07.001

Kleijnen, M., N. Lee, and M. Wetzels. 2009. “An exploration of consumer resistance to innovation and its antecedents." Journal of Economic Psychology 30 (3): 344-357. https://doi.org/10.1016/i.joep.2009.02.004

Knight, F. H. 1921. Risk, uncertainty and profit. Boston: Houghton Mifflin Kuester, S., and S. Hess. 2009. "How to Overcome Customers' Adoption Barriers?" Advances in Consumer Research 36: 783-784.

http://www.acrwebsite.org/volumes/v36/NAACR vol36 59.pdf

Kulviwat, S., G. Bruner, A. Kumar, S. Nasco, and T. Clark. 2007. "Toward a unified theory of consumer acceptance technology." Psychology and Marketing 24 (12): 10591084. https://doi.org/10.1002/mar.20196

Lin, H.-F. 2011. "An empirical investigation of mobile banking adoption: The effect of innovation attributes and knowledge-based trust." International Journal of Information 42 
Management 31: 252-260. https://doi.org/10.1016/j.ijinfomgt.2010.07.006

Mayer, R., J. Davis, and F. Shoorman. 1995. "An integrative model of organizational trust." Academy of Management Review 20 (3): 709-734.

https://doi.org/10.5465/amr.1995.9508080335

Miles, Matthew B., and A. Michael Huberman. 1994. An Expanded Sourcebook of Qualitative Data Analysis, 2nd edition. Thousand Oaks, CA: Sage

Mitchell, V. W. 1999. "Consumer perceived risk: conceptualisations and models." European Journal of Marketing 33 (1/2): 163-195. https://doi.org/10.1108/03090569910249229

Moreau, C., D. Lehmann, and A. Markman. 2001. “Entrenched knowledge structures and consumer response to new products." Journal of Marketing Research 38 (1): 14-29.

Morgan, R., and S. Hunt. 1994. "The commitment-trust theory of relationship marketing." Journal of Marketing 58 (3): 20-38. https://doi.org/10.1177/002224299405800302

Oreg, S., and Y. Berson. 2011. “Leadership and Employees' Reactions to Change: The Role of Leaders' Personal Attributes and Transformational Leadership Style." Personnel Psychology 64 (3): 627- 659. https://doi.org/10.1111/i.1744-6570.2011.01221.x

Oreg, S., and J. Goldenberg. 2015. Resistance to Innovation: Its Sources and Manifestations. Chicago: University of Chicago Press.

Oreg, S. 2003. "Resistance to Change: Developing an Individual Differences Measure." Journal of Applied Psychology 88 (4): 680-693. http://dx.doi.org/10.1037/0021$\underline{9010.88 .4 .680}$ 
Patton, M. Q. (2002). Qualitative research and evaluation methods (3rd ed.). Thousand Oaks, CA: Sage.

Perks, H., and, D. Roberts. 2013. "A review of longitudinal research in the product innovation field, with discussion of utility and conduct of sequence analysis." Journal of Product Innovation Management 30 (6): 1099-1111. https://doi.org/10.1111/ipim.12048 Pizam, A., G. H. Jeong, A. Reichel, H. van Boemmel, J. M. Lusson, L.Steynberg, O. StateCostache, S. Volo, C. Kroesbacher, J. Kucerova, and N. Montmany. (2004). "The Relationship between Risk-Taking, Sensation-Seeking, and the Tourist Behavior of Young Adults: A CrossCultural Study." Journal of Travel Research 42 (3): 251-60.

https://doi.org/10.1177/0047287503258837

Ram, S. 1989. "Successful innovation using strategies to reduce customer resistance. An empirical test." Product Innovation Management 6(1): 2034. https://doi.org/10.1111/1540$\underline{5885.610020}$

Ram, S., and, J. Sheth. 1989. "Consumer resistance to innovations: the marketing problem and its solutions." Journal of Consumer Marketing 6(2): 5-14. https://doi.org/10.1108/EUM0000000002542

Rogers, E. 1983. Diffusion of Innovations (3rd Ed.). New York: The Free Press.

Rogoff, E., M. Lee and D. Suh. 2004. "Who done it? Attributions by entrepreneurs and experts of the factors that cause and impede small business success." Journal of Small Business Management 42 (4): 364-376. https://doi.org/10.1111/i.1540-627X.2004.00117.x 
Rodriguez, I., AM. Williams, and M. Brotons. 2017. "The innovation journey of new-totourism entrepreneurs" Current Issues in Tourism.

https://doi.org/10.1080/13683500.2017.1334763

Sheth, J. 1981. "Psychology of innovation resistance: The less developed concept (LDC) in diffusion research." Research in Marketing 4: 273-282.

Sethi, R., D. Smith, and C. Park. 2001. "Cross-functional product development teams, creativity, and the innovativeness of new consumer products." Journal of Marketing Research 38 (1): 73-85.

Stebbins, R. A. (2001). Exploratory research in the social sciences (Vol. 48). Sage.

Szmigin, I., and G. Foxall. 1998. "Three forms of innovation resistance: The case of retail payment methods." Technovation 18 (6/7): 459-468. https://doi.org/10.1016/S0166$\underline{4972(98) 00030-3}$

Talke, K., and S. Heidenreich. 2014. "How to overcome pro-change bias: incorporating passive and active innovation resistance in innovation decision models." Journal of Product Innovation Management 31 (5): 894-907. https://doi.org/10.1111/ipim.12130

Tracy, S.J. 2013. Qualitative Research Methods. Collecting Evidence, Crafting Analysis, Communicating Impact. Hoboken, NJ: Wiley-Blackwell.

Tussyadiah I., and Wang, D. 2016. "Tourists' attitudes toward proactive smartphone systems." Journal of Travel Research 55 (4): 493508.https://doi.org/10.1177/0047287514563168 45 
Tversky, A., and D. Kahneman. 1986. "Rational Choice and the Framing of Decisions." The Journal of Business 59 (4): 251-278. https://doi.org/10.1007/978-3-642-74919-3_4

Veryzer, R. 1989. "Key factors affecting customer evaluation of discontinuous new products." Journal of Product Innovation Management 15: 136-150.

https://doi.org/10.1016/S0737-6782(97)00075-1

Venkatesh, V., J. Thong, and X. Xu. 2012. "Consumer acceptance and use of information technology: extending the unified theory of acceptance and use of technology." MIS Quarterly 36 (1): 157-178.

Vogt, D. 2013. “Innovation perception from a customer perspective: recognition, assessment, and comprehension of innovations", PhD diss., University of St. Gallen, St. Gallen.

Wang, W., Cole, S. T., \& Chen, J. S. (2018). "Tourist innovation in Air travel." Journal of Travel Research 57 (2): 164-177. https://doi.org/10.1177/0047287516686724

Watts, D. 2003. Six degrees: The science of a connected age. New York, N.Y.; London: W. W. Norton.

Williams A. M., and V. Baláž. 2015. "Tourism, risk and uncertainty: theoretical reflections." Journal of Travel Research 54 (3): 271-287. https://doi.org/10.1177/0047287514523334 
Wu, I., and J-L. Chen. 2005. "An extension of trust and TAM model with TPB in the initial adoption of on-line tax: an empirical study." International Journal Human-Computer Studies 62 (6): 784-808. https://doi.org/10.1016/j.ijhcs.2005.03.003 
Figure 1. Conceptual model

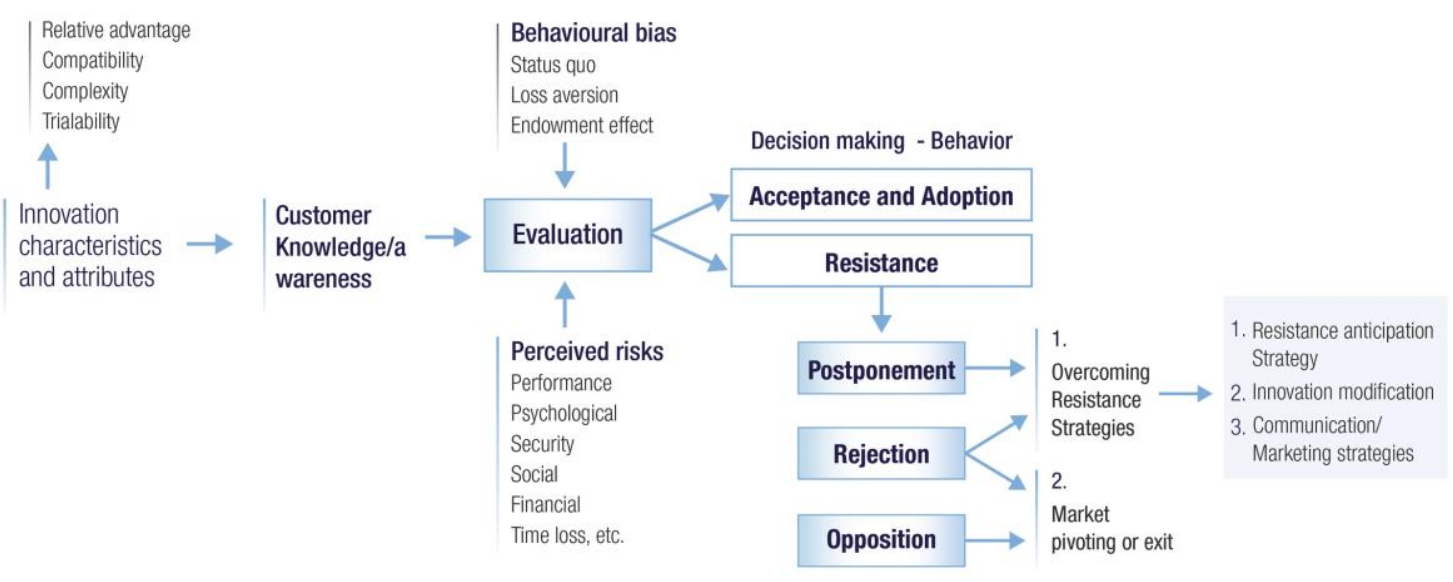


Table 1. Types of innovations

\begin{tabular}{|c|c|c|}
\hline $\begin{array}{l}\text { Entrepreneur } \\
\text { (E) }\end{array}$ & $\begin{array}{l}\text { Intended } \\
\text { customers }\end{array}$ & Description \\
\hline \multicolumn{3}{|c|}{ Accommodation } \\
\hline E1 & $\mathrm{B} 2 \mathrm{C}$ & Eco-friendly only-adults luxury hotel \\
\hline $\mathrm{E} 2$ & $\mathrm{~B} 2 \mathrm{C}$ & Toys-theme hotel for families with children \\
\hline F3 & $\mathrm{B} 2 \mathrm{C}$ & Innovative thematic hotel chain \\
\hline E4 & B2C & Human performance sport resort-hotel \\
\hline \multicolumn{3}{|c|}{ Technology-based services } \\
\hline E5 & B2B & $\begin{array}{l}\text { Virtual tourism agent to provide services of tourism information (human- } \\
\text { computer interactive based on speech and gesture recognition). }\end{array}$ \\
\hline E6 & B2B & $\begin{array}{l}\text { Innovative system to offer guided tours in museums based in augmented reality } \\
\text { technology }\end{array}$ \\
\hline E7 & $\mathrm{B} 2 \mathrm{~B}$ & $\begin{array}{l}\text { Access control and management system for hotels based on the use of } \\
\text { smartphones }\end{array}$ \\
\hline E8 & $\mathrm{B} 2 \mathrm{~B}$ & Thermostat to control the temperature of hotel rooms for costs and energy saving \\
\hline E9 & $\mathrm{B} 2 \mathrm{~B} *$ & $\begin{array}{l}\text { Business intelligence services based on Big Data and IoT for tourism companies } \\
\text { and organisations }\end{array}$ \\
\hline E10 & $\mathrm{B} 2 \mathrm{~B} *$ & Mobile App for an efficient process of supplies management in restaurants \\
\hline E11 & $\mathrm{C} 2 \mathrm{C} *$ & Online platform for in-real time hospitality staff evaluation \\
\hline E12 & $\mathrm{B} 2 \mathrm{~B} *$ & $\begin{array}{l}\text { Smartphone based system to improve performance and quality assessments of } \\
\text { hotels }\end{array}$ \\
\hline E13 & $\mathrm{B} 2 \mathrm{C}^{*}$ & Dry cleaning and laundry delivery App for hotels and holiday apartments \\
\hline E14 & $\mathrm{B} 2 \mathrm{~B} *$ & E-learning platform of English language for hotel staff \\
\hline E15 & $\mathrm{B} 2 \mathrm{~B}$ & Virtual reality teleportation cabin for hotel chains and destinations \\
\hline E16 & $\mathrm{B} 2 \mathrm{~B} *$ & $\begin{array}{l}\text { People management system for hotel businesses (in-real time information to } \\
\text { make decisions on scheduling, financials, HR and training). }\end{array}$ \\
\hline E17 & $\mathrm{B} 2 \mathrm{C} *$ & Revolutionary recruitment service for the hospitality sector \\
\hline E18 & $\mathrm{B} 2 \mathrm{~B} *$ & Restaurant and hospitality customer feedback technology platform \\
\hline E19 & $\mathrm{B} 2 \mathrm{~B} *$ & $\begin{array}{l}\text { Food waste reduction software to help the hospitality sector to reduce food } \\
\text { waste, purchasing and food costs. }\end{array}$ \\
\hline E20 & $\mathrm{B} 2 \mathrm{~B} *$ & $\begin{array}{l}\text { Technological tool to capture and benchmark operating data in Holiday Parks, } \\
\text { Touring \& Camping, Glamping, Luxury Lodges, Cottages \& Farm Complexes }\end{array}$ \\
\hline E21 & $\mathrm{B} 2 \mathrm{C} / \mathrm{B} 2 \mathrm{~B} *$ & App to plan in-destination itineraries and book thousands of activities \\
\hline E22 & $\mathrm{B} 2 \mathrm{~B} *$ & A modelling platform to test entrepreneurial ideas \\
\hline E23 & $\mathrm{B} 2 \mathrm{C} *$ & Platform for food stores and restaurants to sell their surplus food \\
\hline E24 & $\mathrm{B} 2 \mathrm{~B} *$ & Searching platform of locations by travel time \\
\hline E25 & $\mathrm{B} 2 \mathrm{C}^{*}$ & Online platform of reservations for restaurants in Barcelona \\
\hline \multicolumn{3}{|c|}{ Incoming travel services } \\
\hline E26 & $\mathrm{B} 2 \mathrm{~B} *$ & Online platform to offer leisure options at a destination \\
\hline E27 & $\mathrm{B} 2 \mathrm{C}^{*}$ & $\begin{array}{l}\text { Platform that connects travellers with local professionals (tour guides, chauffeur, } \\
\text { interpreters, lawyers) }\end{array}$ \\
\hline E28 & $\mathrm{B} 2 \mathrm{C}^{*}$ & Mobile App personal concierge for the business traveller \\
\hline E29 & $\mathrm{B} 2 \mathrm{C}$ & Guided tours to experience the Costa del Sol fishing tradition \\
\hline
\end{tabular}

E30 B2C* New concept of travel agency which combines online, offline and mobile marketing strategies 


\begin{tabular}{|c|c|c|}
\hline E31 & $\mathrm{B} 2 \mathrm{C}^{*}$ & Online hotel booking platform by hours \\
\hline E32 & $\mathrm{B} 2 \mathrm{C}^{*}$ & Travel agency specialised in dog-friendly accommodation and destinations \\
\hline E33 & $\mathrm{B} 2 \mathrm{C}^{*}$ & Booking platform of worldwide "glamping" accommodation \\
\hline E34 & $\mathrm{B} 2 \mathrm{C}$ & $\begin{array}{l}\text { Experience of the most important Spanish traditions and festivities from inside } \\
\text { as a local }\end{array}$ \\
\hline E35 & $\mathrm{B} 2 \mathrm{C}^{*}$ & Travel agency specialist in family friendly villas \\
\hline E36 & $\mathrm{B} 2 \mathrm{C}^{*}$ & Luxury travel on yachts \\
\hline E37 & $\mathrm{B} 2 \mathrm{C}$ & Creative walking adventures for women \\
\hline E38 & $\mathrm{B} 2 \mathrm{C} *$ & Solo travellers travel agency \\
\hline E39 & $\mathrm{B} 2 \mathrm{C}$ & $\begin{array}{l}\text { Historical and guided tours interpreting the past, the present and the future of the } \\
\text { city }\end{array}$ \\
\hline E40 & $\mathrm{B} 2 \mathrm{C}^{*}$ & Wine and food holiday experiences \\
\hline \multicolumn{3}{|c|}{ Transportation } \\
\hline E41 & $\mathrm{B} 2 \mathrm{C}^{*}$ & Mobile and web application online booking of cab services and chauffeurs \\
\hline \multicolumn{3}{|c|}{ Product innovation } \\
\hline E42 & $\mathrm{B} 2 \mathrm{~B}$ & $\begin{array}{l}\text { A body drier innovation for hotels for economic and environmental savings } \\
\text { compared to towels }\end{array}$ \\
\hline \multicolumn{3}{|c|}{ Others Business concepts } \\
\hline E43 & $\mathrm{B} 2 \mathrm{~B}$ & $\begin{array}{l}\text { Start-up acceleration programme based on the innovative Demium method for } \\
\text { technological start-ups in the tourism sector. }\end{array}$ \\
\hline E44 & $\mathrm{B} 2 \mathrm{C}^{*}$ & A platform for online claims to protect consumer rights in the airline sector \\
\hline \multicolumn{3}{|c|}{ Gastronomy and restaurants } \\
\hline E45 & $\mathrm{B} 2 \mathrm{C}$ & $\begin{array}{l}\text { 3-star restaurant with food and gastronomy research and development lab } \\
\text { (research on plankton, seafood products, bioluminescence, etc.) }\end{array}$ \\
\hline E46 & $\mathrm{B} 2 \mathrm{C}$ & Restaurant chain with a strong component of $R \& D$ in food and gastronomy \\
\hline E47 & $\mathrm{B} 2 \mathrm{C}$ & $\begin{array}{l}\text { A restaurant offering a dining experience staffed by prisoners leading to } \\
\text { employment in the UK hospitality industry upon release. }\end{array}$ \\
\hline E48 & $\mathrm{B} 2 \mathrm{C}$ & Music-theme experience restaurant \\
\hline E49 & $\mathrm{B} 2 \mathrm{C}$ & Exotic food Restaurant \\
\hline E50 & $\mathrm{B} 2 \mathrm{C} / \mathrm{B} 2 \mathrm{~B}$ & Experimental gastronomical events and corporate explorations \\
\hline \multicolumn{3}{|c|}{ Food and beverage } \\
\hline E51 & $\mathrm{B} 2 \mathrm{C}$ & $\begin{array}{l}\text { Distillery of gin offering guided tours and tasting of their product innovation } \\
\text { awarded gin }\end{array}$ \\
\hline E52 & $\mathrm{B} 2 \mathrm{C}$ & $\begin{array}{l}\text { Grab and Go Startup. Veg base + Complex Carb + Protein add-on / Eco-friendly } \\
\text { food for brain and body }\end{array}$ \\
\hline \multicolumn{3}{|c|}{ Social/collaborative networks } \\
\hline E53 & $\mathrm{B} 2 \mathrm{C}^{*}$ & Network of mentoring for women in travel and tourism \\
\hline E54 & $\mathrm{C} 2 \mathrm{C}^{*}$ & International network of house-sitters and homeowners for home and pets care \\
\hline E55 & $\mathrm{C} 2 \mathrm{C}^{*}$ & Collaborative system of mums for the caring of children on holidays \\
\hline E56 & $\mathrm{B} 2 \mathrm{C}^{*}$ & A network for professional women business travellers \\
\hline
\end{tabular}

*Online Business 